\title{
A REVIEW OF MOLECULAR MARKERS TO GENES INVOLVED IN MINERAL NUTRITION EFFICIENCY CONTROL IN RICE (Oryza sativa L.)
}

\section{Yu.K. GONCHAROVA, E.M. KHARITONOV, B.A. SHELEG}

All-Russian Research Institute of Rice, Federal Agency of Scientific Organizations, pos. Belozerniy, Krasnodar, 350921 Russia, e-mail serggontchar@mail.ru (corresponding author)

ORCID: Goncharova Yu.K. orcid.org/0000-0003-2643-7342

The authors declare no conflict of interests

Acknowledgements:

Supported by Russian Foundation for Basic Research (grant № 1644230207 p_a)

Received August 1, 2016

\section{Abstract}

To date, the doses of mineral fertilizers per hectare in Asia and Europe are the highest in the world. This leads to serious problems for environment contamination, including water pollution, an increase in emission of hotbed gases and a decrease of $\mathrm{pH}$ in soils and water. Nitrogen utilization in rice, wheat and corn is 26-30\%, and in vegetables less than $20 \%$ (K. Vinod et al., 2012). During last fifty years high yielding varieties are being bred at high mineral nutrition. An increase in doses of fertilizers has resulted in smaller efficiency of their application and an increasing adverse impact on the environment. As a rule, the varieties which are high productive due to introduced high doses of fertilizers are less effective in their utilization. Besides, productivity of such varieties is very unstable as being considerably influenced by doses of the introduced fertilizers, terms of their introduction, ambient temperature, etc. In the paper we briefly reviewed the mechanisms of plants adaptation to low nitrogen and phosphorus nutrition, and the genotypic distinctions in the efficiency of using these elements. The efficiency is noted to be influenced no only by various responses of genotypes to the applied doses, but also by a source of element and the interactions between a genotype and the environment. Comparison of genotypes of rice has shown 20 -fold distinction in efficiency of phosphorus use between extreme types (M. Wissuwa et al., 2001). All highly effective genotypes are cultivars with age-old longevity or endemics. Most P-containing organic compounds that plants have to extract from soil should be turned into the accessible form by phosphatases. So a genotypic diversity in the efficiency of phosphorus use is related to different activity of phosphatases. Phytin acid produced by roots and the rhizosphere microorganisms is one of the agents promoting phosphorus accessibility (A.E. Richardson et al., 2001). Therefore, the plant ability to support favorable microbial communities in the rhizosphere serves as the additional adaptive mechanism. Plant adaptation to low nitrogen and phosphorus levels can be due to root system development, intensification of absorption and utilization, and also to biosynthesis and excretion of the organic acids to increase availability of the mineral elements in the rhizosphere (H. Lambers et al., 2006). Redistribution of the absorbed elements between generative and vegetative organs, between leaves on one or different stems stands for an internal efficiency of nutrient utilization. Variability on the efficiency of nutrition utilization among 30 rice genotypes resulted mainly from distinctions in the growth of root system which increased the absorbing area. Variability of genotypes on the tolerance to a lack of phosphorus was mainly due to different ability to $\mathrm{P}$ absorption, while the changes in the efficiency of $\mathrm{P}$ utilization were insignificant. OTL related to $\mathrm{N}$ and $\mathrm{P}$ utilization and specific molecular markers flanking the loci, RM 53, RM 25, RM 600, RM 242, RM 235, RM 247, RM 322, RM 13, RM 261, RM 19 (D. Wei et al., 2012; Y. Cho et al., 2007), are found in foreign and domestic rice varieties. In the Russian rice varieties all studied markers to QTL involved in the expression of effective absorption of mineral elements are polymorphic (Yu.K. Goncharova et al., 2015) that allows to use these markers in marker-assisted selection and screening population to reveal donors of desirable traits.

Keywords: rice, mineral nutrition, efficiency of use nitrogen and phosphorus, QTL, microsatellite (SSR) markers

Nitrogen and phosphorus availability is one of the most important factors which determines crop productivity. Nutrient in soil are not replenished when there is shortage of fertilizer, and it leads to soil degradation and low yields [13]. Whiles, over-fertilization at the EU, had led to soil nitrogen accretion, which menaces to $70 \%$ of agrocoenosis. Till now, attention has not been attracted to 
increased inorganic nutrition efficiency in creating varieties of rice and other crops, however, these works are indispensable. It is important to study both mechanism of plant resistance to the soil deficient in mineral nutrients, and genes encoding the traits. In this review the main achievements and challenges in genetics of rice (Oryza sativa L.) inorganic nutrition are discussed as well as outlook for molecular-genetic technologies and increasing its efficiency.

In the last 40 years mineral fertilizers provide $40 \%$ gain in food production. From 1961 to 2002 its using in the world had been increased by almost $350 \%$ (from 33 to 146 million tons) and often causes damage to the environment $[4,5]$. To date, Asia and Europe have the highest rates of fertilizer consumption per hectare. As a consequence, acidification of soil and water is observed, as well as pollution of surface and underground water bodies, increase of hotbed blowout gases. Environmental impact of mineral fertilizers is determined by their quantity, methods and time of application. The problem is to abandon improper methods and move to agriculture, which will provide reliable basis for sustainable intensification of plant growing.

Nitrogen as the main component of many organic molecule, nucleic acids, proteins, is necessary for development of plants much more than another mineral elements. Though $\mathrm{N}$ is the most accessible element in atmosphere (78 \%), it becomes a limiting factor in agricultural ecosystems. Its soil reserves are equal to 2-20 t/ha, but plants receive just small amount of it [3]. Nitrogen use efficiency is $26-30 \%$ for rice, wheat, maize, and makes less than $20 \%$ for vegetable crops [6-8].

Some quantity of ammonium and ammonium fertilizers which accumulates during mineralization of the organic compounds is fixed by soil minerals (illite, montmorillonite, vermiculite and others). Soil nitrogen, as a part of humic compounds, is difficult to decompose by microorganisms. Small amount of nitrogen is a part of another organic compounds such as amino acids, amino sugars, nucleic acids, etc., and also minerals compounds (preferentially ammonium and nitric acid). Ammonium nitrogen pool formed due to ammonification and fertilizers is unstable. Under the influence of nitrifying bacteria, it is oxidized to nitric acid. Nitrates are not absorbed by soil colloid and can be washed out of soil. Also, nitrogen get into the atmosphere because of nitrate nitrogen reduction to free molecular nitrogen $\left(\mathrm{N}_{2}\right)$ or to gaseous oxide or nitrous oxide ( $\mathrm{NO}$ and $\mathrm{N}_{2} \mathrm{O}$ ). Just small amount of nitrogen remains in soil and is available to the next generations of plants. In most cases, on well aerated soils they use nitrate nitrogen $\left(\mathrm{NO}_{3}\right)$, on bad aerated and flooded soils they use ammonium nitrogen $\left(\mathrm{NH}_{4}{ }^{+}\right)$[4]. Although absorption of $\mathrm{NH}_{4}{ }^{+}$needs less energy, only some of plants (including rice) are capable to grow using just these ions [9].

Phosphorus is the second most important mineral in plant nutrition after nitrogen and one of the least available. Mainly, it is in the bound state in the soil. Approximately, 5.7 billion hectares of soils all over the world contain insufficient quantity of plant available phosphorus. Almost $50 \%$ of rice occupied soils are phosphorus poor. Deficit of phosphorus can significantly affect rice growth and development. Plants cultivated on soils with phosphorus deficit are scraggy with dark green leaves, inhibited root system and lowered tillering [4, 5]. Their maturation is delayed, and grains are incompletely filled that leads to loss of grain quality. This deficit could be overcome by fertilizer application which farmers do not apply because of high price. As well as, natural phosphates of earth's formations which easy to accesses for plants are resources which can be exhausted by the end of XXI century [10]. Creating varieties of cultivated plants which are capable of more efficient absorption of bound phosphorus from soil with high yielding at low doses of phosphorus fertilizers and more efficient use of 
absorbed phosphorus has crucial importance [11].

From 2008 to 2012, a steady growth of fertilizer consumption up to $1.7 \%$ (or 15 million tons annually) had been reported, and in 2012 nitrogen consumption raised by $1.4 \%$, or $73 \mathrm{mln}$. t. At the same time there is loss of consumption efficiency per 1 kilo of getting products, and the rate of rice yield gain in 2010 was less than $1 \%$ compared to $1.6 \%$ in 1990 [5]. Other factors which forced to change strategy of fertilizer consumption have become their price growth, limited reserves, and also environment pollution because of uncontrolled use.

Last 50 years efforts is mainly focused on breeding plant varieties with high yield under high mineral nutrition [13]. Application of ever large doses of fertilizers has led to a decrease of their efficiency and an increase of environmental effects on productivity [14]. Moreover, crop yield of these varieties is unstable.

Genotypic differences in the absorption efficiency of elements of mineral nutrition. Not only on nitrogen doses, but on its source genotypes react differently. Genotype $\times$ environment interaction is an important factor as well [15]. There are several parameters of nitrogen consumption among which are nitrogen deficit tolerance (NDT) and nitrogen use efficiency (NUE) [16]. It is detected that samples of rice plants differ genotypically on their ability to take up phosphorus when it is in deficit [17-19]. Comparison of 30 genotypes showed a twenty-fold difference in this parameter between extreme types [20]. All high-efficient genotypes are age-old samples or endemics. Modern high-yielding varieties are not enough adapted to deficit of mineral nutrition.

Plant adaptation to low content of nitrogen and phosphorus can be due to an increase of root surface, intensification of elements absorption and internal efficiency of their use. The internal efficiency is a redistribution of incoming phosphorus between generative and vegetative organs, between leaves of one or different shoots, etc. M. Wissuwa [21] who studied the efficiency of mineral nutrition in 30 rice genotypes, including high-yielding varieties and endemic samples, attributed the variability on this trait to distinctions in the growth of root system and thereafter increasing the plant nutrition area. In rice, resistance to phosphorus shortage is related to ability of genotypes to absorb this element, while internal use efficiency exerts slight influence [21]. With phosphorus shortage plants re-distribute more assimilates to the roots slowing the growth of shoots. A high deficit also impedes the root growth [22, 23]. Effective way to increase root surface is to increase root length and number, and also quantity of root hairs. In Arabidopsis thaliana some mutations affect root development. Homologues of some genes responsible for root hair development are identified in rice genome [24]. However, it has not yet been established whether they differentiate rice genotypes on stable and unstable.

Architectonic modifications of the root system in soil connected with stability to the phosphorus shortage were marked in white lupine and other legumes and rice. Absorbing root capacity is the main factor of adaptation to phosphorus shortage in legumes [26]. Meaning of this mechanism in an increase of rice plant stability to $\mathrm{P}$ shortage has not been determined. Differences in the root length do not always provide distinction in efficiency of absorption of mineral elements [22]. So it is necessary to consider all interconnected factors that control adaptation. Factors involved in effective remobilization and relocation of phosphorus and nitrogen in plants, and regulation of this processes at the genome level are studied a little [27, 28].

The most part of phosphorus can be found in soils in organic complexes which are converted by phosphatases to form available for plants. In wheat, the 
genotypic differences in phosphorus use efficiency are expressed as not identical phosphatase activity [29, 30]. Such differences have not been found in rice [23]. Soils often contain phytic acid (substance which conduces conversion of fixed phosphorus to the available), but plant roots excrete it in very small amounts, while microorganisms can produce much more acid, so ability of roots to support useful microbial community serves as an additional adaptive mechanism [31]. The majority of plants, as rice, are able to symbiotic associations with mycorrhizal fungi. These interactions are genetically determined [14]. But for Nipponbare variety, soil sterilization did not reduce efficiency of phosphorus absorption [21]. Organic acid biosynthesis and secretion by rhizosphere, which increase availability of elements, positively affected the tolerance of wheat, barley, and rice plants to nitrogen, zinc and phosphorus deficit [32,33].

Prospects of improving rice varieties one links with identification of the genetic determinants of tolerance to mineral element deficit and their introduction to high yielding varieties using MAS methods.

Quantitative trait loci (QTL) which determine tolerance to nitrogen deficit. In marking different rice populations, from 7 to 8 QTL linked to nitrogen-deficiency tolerance (NDT) was identified on the chromosomes $1,2,3,4,7,9,10$ and 11 . NDT is the ratio of the trait value at low nitrogen ( $\mathrm{LN}, 0 \mathrm{~kg} / \mathrm{ha}$; mostly without additional fertilizers) to its value at optimal mineral nutrition (NN, $130 \mathrm{~kg} / \mathrm{ha})$.

Indicators of varietal adaptation to nitrogen deficiency are plant productivity, the yield per plot, biomass, plant height, root length, the content of pigments, etc. [34-36]. But analysis of these traits showed that high relative biomass value was characteristic of the genotypes with low total biomass [35]. The most informative indicators were the relative grain yield (grain yield LN/grain yield $\mathrm{NN}) \times 100$, relative biomass, relative nitrogen content in grain and in biomass, nitrogen response ( $\mathrm{NR} \mathrm{kg} / \mathrm{ha}$, as $\mathrm{TNf}-\mathrm{TNo}$, the difference between nitrogen consumption by the plant at optimum and low mineral nutrition).

Nitrogen use efficiency is determined as the difference between the values at optimal and low mineral nutrition [36], and physiological NUE (PE, kg grain/kg nitrogen) is the ratio of the grain yield response (GYf - GYc) to the total response to nitrogen $(\mathrm{TNf}-\mathrm{TNo})$.

QTL for NUE were mapped on chromosomes 1, 2, 3, 4, 6, 7, 9, 10 and 11 in rice variety of subspecies indica (Zhenshan $97 \times$ Minghui 63) (Table 1) [33-40]. Four genomic regions in chromosomes 1, 3, 4 and 7 involved in expression of both studied traits, NDT and NUE, are flanked by markers G393-C922, RM232-C63, G235-G102 and RG678-R1440, receptively. However, phenotypic manifestation of many of detected loci was influenced by year conditions (weather or others unaccounted factors) [34]. Three chromosomal segments mapped in chromosomes 4, 6 and 10 were linked to maximum nitrogen response determining $11.1 ; 16.6$ and $7.5 \%$ of the trait phenotypic manifestation, respectively. In this work, dry biomass was measured by cutting plants to the root and dried at $75{ }^{\circ} \mathrm{C}$ for 4 days, and nitrogen was assessed by Kjeldahl method. There was a negative correlation between indicated traits [36]. In another research [37], the loci were allocated which determine much higher phenotypic manifestation of the trait in the rice varieties of subspecies japonica. So, $32.1 \%$ of grain nitrogen level was controlled by QTL $n c g$ 8.2, mapped on chromosome 8 and flanked by markers S8055-RM72. The crop yield index in stress was $23.1 \%$ influenced by locus hi7b on chromosome 7 flanked by SSR markers RM420RM248 (Table 2). Plant biomass was determined by locus sy8.1 (23.8\%) of chromosome 8 with flanking markers S8055-RM72 [38]. 
1. QTL for nitrogen use efficiency detected in varieties of rice (Oryza sativa $\mathrm{L}$.) subspecies indica (Zhenshan $97 \times$ Minghui 63) [37]

\begin{tabular}{|c|c|c|c|c|c|c|}
\hline Trait & 1 & 2 & 3 & 4 & 5 & 6 \\
\hline Relative grain yield, \% (RGY) & $q R G Y 3$ & $3(2006)$ & RM232-C63 & 180.2 & $171.2-190.6$ & 10.8 \\
\hline \multirow{4}{*}{ Relative biomass, $\%$ (RBM) } & $q R B M 9-2$ & $9(2006)$ & RM242-RM257 & 35.5 & $32.0-41.6$ & 13.1 \\
\hline & $q R B M 1$ & $1(2007)$ & RG101-C922 & 70.8 & $66.9-78.2$ & 11.5 \\
\hline & $q R B M 2$ & $2(2007)$ & C777-R1843 & 28.4 & $23.7-32.1$ & 9.3 \\
\hline & $q R B M 4$ & 4 (2007) & G235-G102 & 42.3 & $33.1-51.6$ & 14.5 \\
\hline \multirow[t]{2}{*}{ Relative grain nitrogen, \% (RGN) } & $q R G N 9$ & 9 (2006) & RG667-RG570 & 20.5 & $16.3-27.8$ & 8.6 \\
\hline & $q R G N 1$ & $1(2006-2007)$ & G393-RG101 & 67.9 & $66.0-74.3$ & 13.2 \\
\hline hass nitrogen, $\%$ & $q R B N 2$ & $2(2006-2007)$ & RZ599-RM53 & 54.5 & $48.8-59.4$ & 8.9 \\
\hline \multirow[t]{2}{*}{$(\mathrm{RBN})$} & $q R B N 9$ & $9(2006)$ & RG667-RG570 & 18.2 & $10.8-24.5$ & 9.4 \\
\hline & $q R B N 4-2$ & $4(2007)$ & G235-G102 & 42.3 & $41.6-48.0$ & 14.6 \\
\hline \multirow[t]{3}{*}{ Nitrogen response, $\mathrm{kg} / \mathrm{ha}(\mathrm{NR})$} & $q N R 6$ & $6(2006)$ & RZ398-C764 & 167.3 & $165.3-170.6$ & 16.6 \\
\hline & qNR10 & $10(2006)$ & R2625-RG561 & 8.6 & $4.0-11.4$ & 7.5 \\
\hline & $q N R 4$ & $4(2007)$ & G235-G102 & 42.3 & $36.6-57.5$ & 11.01 \\
\hline \multirow[t]{4}{*}{ Grain yield response, $\mathrm{kg} / \mathrm{ha}(\mathrm{GR})$} & $q G R 3$ & $3(2006)$ & RM232-C63 & 180.2 & $170.5-185.3$ & 16.2 \\
\hline & $q G R 9$ & 9 (2006) & C472-RM201 & 77.4 & $57.4-95.7$ & 12.5 \\
\hline & $q G R 1-1$ & $1(2007)$ & RM212-R2201 & 49.0 & $46.3-57.8$ & 12.9 \\
\hline & $q G R 1-2$ & $1(2006)$ & G393-RG101 & 66.9 & $63.2-75.0$ & 9.9 \\
\hline \multicolumn{2}{|c|}{ Physiological nitrogen-use efficiency, $q P E 3$} & $3(2006-2007)$ & RM232-C63 & 180.2 & $166.2-185.3$ & 12.8 \\
\hline $\mathrm{kg}$ grain/kg nitrogen $(\mathrm{PE})$ & $q P E 7$ & 7 (2007) & RG678-R1440 & 68.9 & $50.6-76.2$ & 8.8 \\
\hline \multicolumn{7}{|c|}{$\begin{array}{l}\text { N ot i c e. } 1-\text { locus; } 2-\text { chromosome (year); } 3-\text { flanking markers; } 4-\text { the most probable gene position, cM; } 5- \\
\text { position on the chromosome, cM; } 6-\text { phenotypic manifestation of traits, } \% ; R G Y=\left(\mathrm{GY}_{0} / \mathrm{GY}_{\mathrm{F}}\right) \times 100 ; \\
\mathrm{RBM}=\left(\mathrm{BM}_{0} / \mathrm{BM}_{\mathrm{F}}\right) \times 100 ; \mathrm{RGN}=\left(\mathrm{GN}_{0} / \mathrm{GN}_{\mathrm{F}}\right) \times 100 ; \mathrm{RBN}=\left(\mathrm{BN}_{0} / \mathrm{BN}_{\mathrm{F}}\right) \times 100 ; \mathrm{NR}=\mathrm{TN}_{\mathrm{F}}-\mathrm{TN}_{0} ; \\
\mathrm{GR}=\mathrm{GY}_{\mathrm{F}}-\mathrm{GY}_{0} ; \mathrm{PE}=\left(\mathrm{GY}_{\mathrm{F}}-\mathrm{GY}_{0}\right) /\left(\mathrm{TN}_{\mathrm{F}}-\mathrm{TN}_{0}\right) ; \mathrm{GN}_{0} \text { and } \mathrm{GN}_{\mathrm{F}} ; \mathrm{BM}_{0} \text { and } \mathrm{BM}_{\mathrm{F}} ; \mathrm{BN}_{0} \text { and } \mathrm{BN}_{\mathrm{F}} ; \mathrm{TN}_{0} \text { and } \\
\mathrm{TN} \mathrm{FY}_{\mathrm{F}} ; \mathrm{GY}_{0} \text { and } \mathrm{GY} \mathrm{F}-\text { nitrogen content in grain; biomass; nitrogen content in biomass; nitrogen content per plant; } \\
\text { grain yield (no fertilizer }-0 \text {, fertilizer application }-\mathrm{F}) \text {. }\end{array}$} \\
\hline
\end{tabular}

2. QTL for nitrogen use efficiency detected in varieties of rice (Oryza sativa L.) subspecies japonica [38]

\begin{tabular}{|c|c|c|c|c|}
\hline Trait & Locus & Chromosome & Flanking markers & Trait manifestation, $\%$ \\
\hline \multirow[t]{4}{*}{ Nitrogen content in grain (NCG) } & $n c g 8.1$ & 8 & RM25-S8090 & 10.2 \\
\hline & $n c g 9$ & 9 & S9058-S9062 & 10.2 \\
\hline & ncg 10 & 10 & S10023-S1001B & 7.5 \\
\hline & $n c g 8.2$ & 8 & S8055-RM72 & 32.1 \\
\hline \multirow[t]{2}{*}{ Nitrogen content in straw (NCS) } & $n c s 9$ & 9 & S9093-S9073 & 11.1 \\
\hline & $n c s 10$ & 10 & S10019-S1001B & 13.3 \\
\hline \multirow{2}{*}{ Nitrogen content in shoots(TNCS) } & $\operatorname{tncs} 1 b$ & 1 & RM600-RM312 & 19.7 \\
\hline & $\operatorname{tncs} 10$ & 10 & S1003-S10013 & 14.1 \\
\hline \multirow[t]{2}{*}{ Harvest index (HI) } & $h i 5 b$ & 5 & RM87-RM31 & 8.7 \\
\hline & $h i 7 b$ & 7 & RM420-RM248 & 23.1 \\
\hline \multirow[t]{2}{*}{ Grain yield $(\mathrm{GY})$} & $g y 2 b$ & 2 & S2052-S2054 & 6.9 \\
\hline & gy 9 & 9 & RM242-RM215 & 12.9 \\
\hline \multirow[t]{7}{*}{ Straw biomass (SY) } & sylb & 1 & RM600-RM312 & 12.1 \\
\hline & sy 8.1 & 8 & S8055-RM72 & 23.8 \\
\hline & sy 8.2 & 8 & RM25-S8090 & 8.4 \\
\hline & sy $5 a$ & 5 & S5014B-S5029 & 9.6 \\
\hline & $s y 5 b$ & 5 & RM87-RM31 & 9.1 \\
\hline & $s y 7 b$ & 7 & RM420-RM248 & 8.4 \\
\hline & $s y 12 b$ & 12 & S12038-RM277 & 9.9 \\
\hline Physiological N-use efficiency (PNUE) & рпие9 & 9 & S9093-S9073 & 15.3 \\
\hline
\end{tabular}

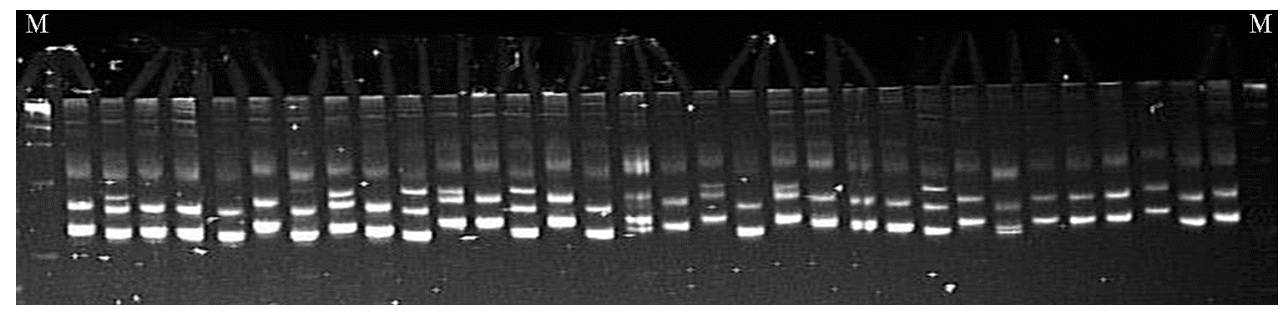

Fig. 1. Polymorphism of Russian rice (Oryza sativa L.) varieties on marker RM 600 to genes for nitrogen use efficiency: from left to right - Hankai, Sadko, Primorskii, Liman, Garant, Pavlovskii, Rapan, Novator, Serpantin, Boyarin, Regul, Yantar, Zhemchug, Lider, Khazar, Amethyst, Narciss, Druzhnyi, Sprint, Viola, Dal'nevostochnyi, Fontan, Kasun, Yupiter, Atlant, Kurchanka, Fakel, Snezhinka, Sharm, Anait, Flagman, Izumrud; $M$ is a molecular weight marker [12].

Study of Russian varieties using molecular markers to genes for nitrogen 
use efficiency showed polymorphism in some of them [12]. The maximum number of polymorphic alleles was found using the marker RM 600 located on chromosome 1 (Table 3, Fig. 1).

3. Polymorphism of Russian rice (Oryza sativa L.) varieties on SSR markers to genes for nitrogen use efficiency [12]

\begin{tabular}{|c|c|c|c|c|}
\hline Marker & Trait & $\begin{array}{l}\text { Fragment } \\
\text { size, bp }\end{array}$ & Chromosome & Polymorphism \\
\hline RM 53 & Relative biomass nitrogen (RBN) & 182 & 2 & $\begin{array}{l}\text { Polymorphic, } \\
2 \text { alleles }\end{array}$ \\
\hline RM 25 & $\begin{array}{l}\text { Straw yield (SY), nitrogen content in grain (NCG), } \\
\text { drought adaptiveness, photosynthetic efficiency }\end{array}$ & 146 & 8 & $\begin{array}{l}\text { Polymorphic, } \\
2 \text { alleles }\end{array}$ \\
\hline RM 600 & Nitrogen content in shoots (TNCS), straw yield (SY) & 220 & 1 & $\begin{array}{l}\text { Polymorphic, } \\
5 \text { alleles }\end{array}$ \\
\hline RM 242 & $\begin{array}{l}\text { Grain yield (GY), relative biomass nitrogen (RBM), } \\
\text { adaptiveness to law temperatures }\end{array}$ & 225 & 9 & $\begin{array}{l}\text { Polymorphic, } \\
2 \text { alleles }\end{array}$ \\
\hline
\end{tabular}

Markers RM 242, RM 53, RM 25 showed 2 alleles. This polymorphism allows marker-assisted selection (MAS) for nitrogen use efficiency, and identification of donors of appropriated genes among Russian varieties. Interestingly, these markers were also associated to adaptiveness to other stresses (drought, low temperature).

QTL associated to tolerance to phosphorus deficiency. Although the wide genetic variability on this trait, the progress in breeding rice varieties, which are high-yielding and effectively use phosphorus, is small. It is found that inheritance of traits, associated to phosphorus shortage tolerance is largely specified by two independent QTL [41]. The basic locus named Pup1 and flanked by the RM235 and RM247 markers separated by a distance of $0.2 \mathrm{cM}$ is located on chromosome 12. Using the flanking markers, the Pup1 gene was identified in the verities Dular, IAC 47, IAC 25, AUS 257, and Vary Lava 701. Clusterization of 80 varieties carrying different allelic variant of gene Pup1 identified the allele associated to tolerance in varieties adopted to drought. Practically, this allele was not find in the varieties cultivated under irrigation. Donor varieties have longer and more branchy root system in comparison to others genotypes, that confirms necessity of selection for this trait when creating forms tolerant to phosphorus deficiency. Molecular markers were successfully used in introgression of Pup1 gene to stress sensitive varieties IR64, IR74, Dodokah, Batur, and Sity Bagendit [42, 43]. The Pup1 gene determines almost $80 \%$ of phenotypic differences in the population [21].

A locus with less significant effect was detected in chromosome 6. QTL on chromosome 6 determined 25-34\% phenotypic differences in this trait, but field trials showed its less effect [23]. Few minor loci were mapped on other chromosomes [43-45]. Some of these QTL were located in the same chromosomal regions as the gene-candidates for phosphorus shortage tolerance which were identified earlier.

In another marked population (Kasalath $\times$ Gimbozu) QTL, causing roots elongation with shortage of phosphorus, is also mapped on chromosome 6 [45]. Later, several loci involved in phosphorus metabolism were detected on chromosomes 1, 2, 5, and 9 [43]. As a rule, the genes determining adaptiveness is situated in clusters, however, another genes associated to the traits, except Pup1 on chromosome 12, were not detected. The positive effect of Pup1 gene was more clear when phosphorus shortage was coincide with water shortage.

The distance between other markers, which flank the genes encoding tolerance to phosphorous shortage does not exceed $12.9 \mathrm{cM}$. It allows us to involve them in genetic and selection researches, because use of two markers to control allele introgression significantly reduces the probability of dual crossing and 
increases the reliability of estimates. For two flanking markers with a distance of $10 \mathrm{cM}$ the probability of false gene identification is not more than $1.2 \%$, which is lower than admitted in biological research [35]. In more recent papers, the effective use of selected markers in control of introgression was shown in different population.

Polymorphism of Russian and foreign varieties has been shown with all investigated markers to genes encoding effective use of phosphorus, which makes it possible to involve them in breeding [46-48]. The maximum number of alleles is noted for RM 247 (chromosome 12) (Fig. 2). All Russian varieties, except Yantar, Dal'nevostochnyi, Anait, are monomorphic in their RM 322 marker. There are three alleles for RM13 (in varieties Pavlovskii, Boyarin, Regul, Yantar, Druzhnyi, Kasun the size of amplified DNA fragments is bigger than in most others), and two alleles for RM 261 (molecular weight of the fragments is bigger in the varieties Sadko, Novator, and Regul).

A

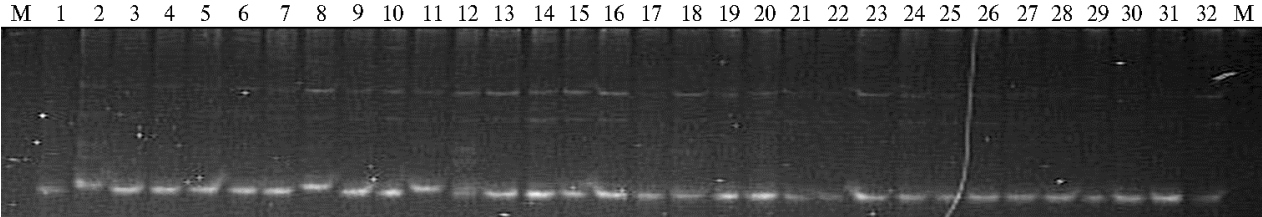

B
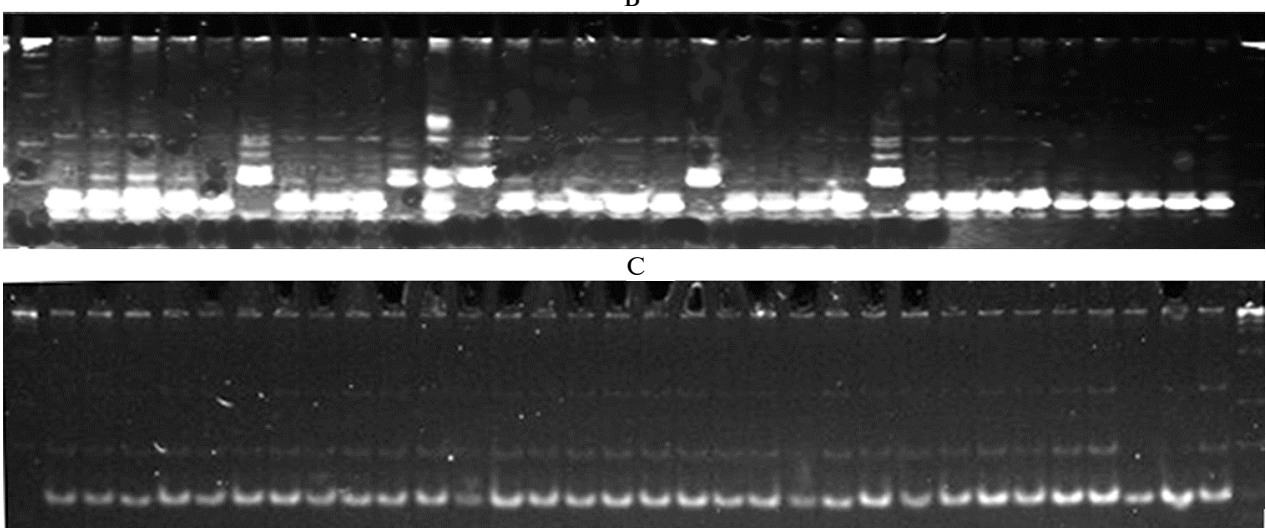

$\mathrm{D}$

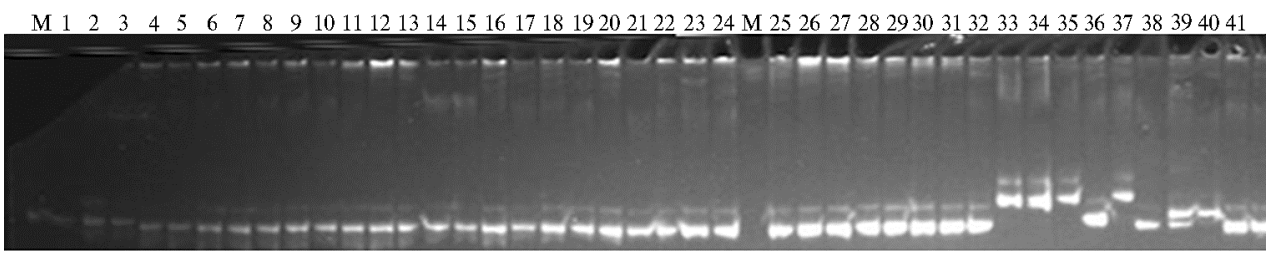

Fig. 2. Polymorphism of Russian and foreign rice varieties (Oryza sativa L.) on markers RM 261 (A), RM 13 (B), RM 322 (C) and RM 19 (D) to genes for effective use of phosphorus: 1 - Khankai, 2 Sadko, 3 - Primorsky, 4 - Liman, 5 - Garant, 6 - Pavlovskii, 7 - Rapan, 8 - Novator, 9 Serpentine, 10 - Boyarin, 11 - Regul, 12 - Yantar, 13 - Zhemchug, 14 - Leader, 15 Khazar, 16 - Amethyst, 17 - Narciss, 18 - Druzhnyi 19 - Sprint, 20 - Viola, 21 Dal'nevostochnyi, 22 - Fotan, 23 - Kasun, 24 - Yupiter, 25 - Atlant, 26 - Kurchanka, 27 Fakel, 28 - Snezhinka, 29 - Sharm, 30 - Anait, 31 - Flagman, 32 - Izumrud; 33 - IR 66, 34 NSIC RC 158, 35 - IR68897B, 36 - IR 73328B (donors of genes WC); 37 - Moroberican, 38 N 22, 39 - Azusena, 40 - Dular, - - Taipei 309; M is a molecular weight marker [48].

All studied markers associated to phosphorus absorption capability of plants are suitable for breeding and selection of donor genotypes among Russian varieties because it is shown that the donor and recipient varieties carry different target alleles, so the plants receiving the donor allele can be detected by electro- 
Thus, mechanisms for plants adaptation to low nitrogen and phosphorus levels in soil are associated to growth and development of root system, intensification of absorption and internal efficiency of the elements use, and also to their availability due to synthesis and excretion of organic acids to the rhizosphere. Crops differ genotypically in the efficiency of nitrogen and phosphorus utilization. The variability in this trait among rice genotype is mainly due to differences in root system growth, which increases its absorbing surface, and to genotypic differences in capability to absorb mineral nutrients, while the change of internal efficiency of their use affects slightly. There is a set of molecular markers associated to studied traits. In Russian rice verities all studied markers associated to efficiency of mineral element intake are polymorphic. All this allows more effective seeking for donors of the target genes and facilitates breeding by using molecular markers.

\section{REFERENCES}

1. Goncharova Yu.K., Litvinova E.V., O ch k as N.A. Trudy Kubanskogo gosudarstvennogo agrarnogo universiteta, 2010: 54-58 (in Russ.).

2. Go $\mathrm{nch}$ a rova Yu.K. Inheritance of determinants specific for physiological heterosis basis in rice hybrids. Agricultural Biology, 2010, 5: 72-78.

3. Kharitonov E.M., Go ncharova Y.K. Mineral nutrient efficiency of rice. Russian Agricultural Sciences, 2011, 37(2): 103-105 (doi: 10.3103/S1068367411020133).

4. B at je s N.H. A world data set of derived soil properties by FAOUNESCO soil unit for global modeling. Soil Use Manage, 1997, 13: 9-16 (doi: 10.1111/j.1475-2743.1997.tb00550.x).

5. Doberma n $\mathrm{n}$ A., F a i rhurst T. Rice: nutrient disorders and nutrient management. Oxford Graphic Printers Pte Ltd, 2000: 60-71.

6. Fage ri a N.K., B a lig a r V.C. Upland rice genotypes evaluation for phosphorus use efficiency. J. Plant Nutr., 2010, 20:499-509 (doi: 10.1080/01904169709365270).

7. L e a P.J., M ifli in B.J. Nitrogen assimilation and its relevance to crop improvement. In: Annual plant reviews. V. 42. Nitrogen metabolism in plants in the post-genomic era. C.H. Foyer, H. Zhang (eds.). Wiley-Blackwell, Oxford, UK, 2010 (doi: 10.1002/9781444328608.ch1).

8. Vin od K.K., H e u e r S. Approaches towards nitrogen- and phosphorus-efficient rice. $A o B$ Plants, 2012: pls028 (doi: 10.1093/aobpla/pls028).

9. Hu ang Y.Z., F e ng Z.W., Z h a n g F.Z. Study on loss of nitrogen fertilizer from agricultural fields and countermeasure. Journal of the Graduate School of Academia Sinica, 2000, 17: 49-58.

10. Ru ng e-Metzge r A. Closing the cycle: obstacles to efficient P management for improved global food security. In: Phosphorus in the global environment: transfers, cycles and management. H. Tiessen (ed.). NY, 1995: 27-42.

11. Food and Agriculture Organization of the United Nations. Current world fertilizer trends and outlook to 2011/12. FAO, Rome, Italy, 2008.

12. Go n c ha rova Yu.K., K harito nov E.M. Vavilovskii zhurnal genetiki $i$ selektsii, 2015, 19(2): 197-204 (doi: 10.18699/VJ15.025) (in Russ.).

13. Hammond J.P., B roadley M.R., White P.J. Genetic responses to phosphorus deficiency. Ann. Bot., 2004, 94: 323-332 (doi: 10.1093/aob/mch156).

14. Guimil S., Chang H.S., Zhu T., Sesma A., Osbourn A., Roux C., Ioannid is V., O akeley E.J., D oc qui e r M., D es combes P., B riggs S.P., Paszk owski U. Comparative transcriptomics of rice reveals an ancient pattern of response to microbial colonization. PNAS USA, 2005, 102: 8066-8070 (doi: 10.1073/pnas.0502999102).

15. $\mathrm{P}$ i a o Z., $\mathrm{Ch}$ o Y.I., K o h H.J. Inheritance of physiological nitrogen-use efficiency and relationship among its associated charaters in rice. Korean J. Breed., 2001, 33: 332-337.

16. Li B.Z., Merrick M., Li S.M., Li H.Y., Zhu S.W., Shi W.M., S u Y.H. Molecular basis and regulation of ammonium transporter in rice. Rice Science, 2009, 16: 314-322.

17. Kirk G.D., George T., Courtois B., Senadhira D. Opportunities to improve phosphorus efficiency and soil fertility in rainfed lowland and upland rice ecosystems. Field Crops Res., 1998, 56: 73-92 (doi: 10.1016/S0378-4290(97)00141-X).

18. Peng S., Yang J., Lasa R., Sanico A., Visperas R., S o n T. Physiological bases of heterosis and crop management strategies for hybrid rice in the tropics. Proc. Int. Conf. "Hybrid rice for food security, poverty alleviation, and environmental protection». Hanoi, 2003: 153-173.

19. Wis suwa M., Wegne r J., A e N., Y a no M. Substitution mapping of Pup 1: a major QTL increasing phosphorus uptake of rice from a phosphorus-deficient soil. Theor. Appl. Genet., 2002, 105: 890-897 (doi: 10.1007/s00122-002-1051-9). 
20. Wis s uw a M., A e N. Genotypic variation for tolerance to phosphorus deficiency in rice and the potential for its exploitation in rice improvement. Plant Breeding, 2001, 120: 43-48 (doi: 10.1046/j.1439-0523.2001.00561.x).

21. Wissuwa M. Combining a modeling with a genetic approach in establishing associations between genetic and physiological effects in relation to phosphorus uptake. Plant Soil, 2005, 269: 57-68 (doi: 10.1007/s11104-004-2026-1).

22. Wis s uw a M. How do plants achieve tolerance to phosphorus deficiency? Small causes with big effects. Plant Physiol., 2003, 133: 1947-1958 (doi: 10.1104/pp.103.029306).

23. W i s s u w a M., G a m a t G., I s m a i 1 A.M. Is root growth under phosphorus deficiency affected by source or sink limitations. J. Exp. Bot., 2005, 56: 1943-1950 (doi: 10.1093/jxb/eri189).

24. G o n c h a r o v Yu.K. Geneticheskie osnovy povysheniya produktivnosti risa. Doktorskaya dissertatsiya [Genetical bases of increasing rice productivity. DSc Thesis]. Krasnodar, 2014 (in Russ.).

25. Lambers H., Shane M.W., Cramer M.D., Pearse S.J., Veneklaas E.J. Root structure and functioning for efficient acquisition of phosphorus: matching morphological and physiological traits. Ann. Bot., 2006, 98: 693-713 (doi: 10.1093/aob/mcl114).

26. S h a n e M.W., L a m be rs H. Cluster roots: a curiosity in context. Plant Soil, 2005, 274: 99123 (doi: 10.1007/s11104-004-2725-7).

27. Misson J., Raghothama K.G., Jain A., Jouhet J., Block M.A., Bligny R., Ortet P., Creff A., Somerville S., Rolland N., Doumas P., Nacry P., Herrerra-Estrella L., Nussaume L., Thibaud M.C. Agenome-wide transcriptional analysis using Arabidopsis thaliana. Affymetrix gene chips determined plant responses to phosphate deprivation. PNAS USA, 2005, 102: 11934-11939 (doi: 10.1073/pnas.0505266102).

28. Morcuende R., Bari R., Gibon Y., Zheng W., Pant B.D., Blasing O., Usade 1 B., Czechowski T., Udvardi M.K., Stitt M., Scheible W.R. Genome-wide reprogramming of metabolism and regulatory networks of Arabidopsis in response to phosphorus. Plant, Cell \& Environment, 2007, 30: 85-112 (doi: 10.1111/j.1365-3040.2006.01608.x).

29. M a r s chner P., S o la i m a n Z., R e nge 1 Z. Rhizosphere properties of Poaceae genotypes under P-limiting conditions. Plant Soil, 2006, 283: 11-24 (doi: 10.1007/s11104-005-8295-5).

30. Radersma S., Grie rs o n P.F. Phosphorus mobilisation in agroforestry: organic anions, phosphatase activity and phosphorus fractions in the rhizosphere. Plant Soil, 2004, 259: 209-219 (doi: 10.1023/b:plso.0000020970.40167.40).

31. Richardson A.E., $\mathrm{H}$ adobas P.A., $\mathrm{H}$ a y e s J.E. Extracellular secretion of Aspergillusphytase from Arabidopsis roots enables plants to obtain phosphorus from phytate. Plant J., 2001, 256: 641-649.

32. R e n g e 1 Z., R o m h e $1 \mathrm{~d}$ V., M a r s c h n e r H. Uptake of zinc and iron by wheat genotypes differing in tolerance to zinc deficiency. J. Plant Physiol., 1998, 152: 433-438 (doi: 10.1016/S0176-1617(98)80260-5).

33. Suzuki M.T., Takashi T., Satoshi W., Shinpei M., Junshi Y., Naoki K., Shoshi K., Hiromi N., S at oshi M., N a oko K.N. Biosynthesis and secretion of mugineic acid family phytosiderophores in zinc deficient barley. Plant J., 2006, 48: 85-97 (doi: 10.1111/j.1365-313x.2006.02853.x).

34. Nguyen B.D., B rar D.S., Bui B.C., N guye $n$ T.V., P ham L.N., Nguye n H.T. Identification and mapping of the QTL for aluminum tolerance introgressed from the new source, Oryza rufipogon Griff., into indica rice (Oryza sativa L.). Theor. Appl. Genet., 2003, 106: 583-593 (doi: 10.1007/s00122-002-1072-4).

35. Y e G., S mith K.F. Marker-assisted gene pyramiding for cultivar development. In: Plant Breeding Reviews, V. 33. J. Janick (ed.). John Wiley \& Sons, Inc., Hoboken, 2010 (doi: 10.1002/9780470535486.ch5).

36. Zhang Y.J., Dong Y.J., Zhang J.Z., Xia o K., Xu J.L., T e rao H. Mapping QTLs for deficiency phosphorus response to root-growth of rice seedling. Rice Genetics Newsletter, 2006, 25:36-37.

37. We i D., Cui K., P a n J., Xi ang J., Hu ang J., N i e L. QTL mapping for nitrogen-use efficiency and nitrogen-deficiency tolerance traits in rice. Plant Soil, 2012, 359: 281-295 (doi: 10.1007/s11104-012-1142-6).

38. Cho Y., Jiang W., Chi n J., Pi a o Z., Cho Y., M c Couch S.R., Koh H. Identification of QTLs associated with physiological nitrogen use efficiency in rice. Mol. Cells, 2007, 23, 1: 72-79.

39. P e ng S., I s m a i 1 A.M. Physiological basis of yield and environmental adaptation in rice. In: Physiology and biotechnology integration for plant breeding. H.T. Nguyen, A. Blum (eds.). NY, 2004: 83-140.

40. Chin J.H., Gamuya o R., Dalid C., Bustamam M., Prasetiyono J., Moe1jo pawi ro S., Wis s uw a M., He u e rm S. Developing rice with high yield under phosphorus deficiency: Pup1 sequence to application. Plant Physiol., 2011, 156: 1202-1216.

41. Su J., Xiao Y., Li M., Liu Q., Li B., Tong Y., Jia J., Li Z. Mapping QTLs for phosphorus-deficiency tolerance at wheat seedling stage. Plant Soil, 2006, 281: 25-36 (doi: 10.1007/s11104-005-3771-5). 
42. L a $\mathrm{g} g$ N., B u u B. Mapping QTLs for phosphorus deficiency tolerance in rice (Oryza sativa L.). Omon Rice, 2006, 14: 1-9.

43. Ni J.J., Wu P., Senadhira D., Huang N. Mapping QTLs for phosphorus deficiency tolerance in rice (Oryza sativa L.). Theor. Appl. Genet., 1998, 97: 1361-1369 (doi: 10.1007/s001220051030).

44. X u Y., C r o u c h J.H. Marker-assisted selection in plant breeding: from publications to practice. Crop Sci., 2008, 48: 391-407 (doi: 10.2135/cropsci2007.04.0191).

45. Rariasca-Tanaka J., S at o h K., Rose T., Maule o n R., Wis suwa M. Stress response versus stress tolerance: a transcriptome analysis of two rice lines contrast in tolerance to phosphorus deficiency. Rice, 2009, 2:167-185.

46. Runge-Metzge r A. Closing the cycle: obstacles to efficient P management for improved global food security. In: Phosphorus in the global environment: transfers, cycles and management. H. Tiessen (ed.). NY, 1995: 27-42.

47. Shimizu A., Yanagihara S., Kaw as a i S., Ike has hi H. Phosphorus deficiency - induced root elongation and its QTL in rice (Oryza sativa L.). Theor. Appl. Genet., 2004, 109: 1361-1368 (doi: 10.1007/s00122-004-1751-4).

48. G o n c harova Yu.K., K harit o nov E.M. Geneticheskie osnovy povysheniya produktivnosti risa [Genetic approach to improving rice productivity]. Krasnodar, 2015 (in Russ.). 